\title{
DISPERSAL OF THE EGG PARASITOID Gryon gallardoi (BRETHES) (HYMENOPTERA: SCELIONIDAE) IN TOBACCO CROPS
}

\author{
CANTO-SILVA, C. R. ${ }^{1}$, KOLBERG, R. ${ }^{2}$, ROMANOWSKI, H. P. ${ }^{1,2}$ and REDAELLI, L. R. ${ }^{1,3}$ \\ ${ }^{1}$ PPG Biologia Animal, UFRGS, Av. Bento Gonçalves, 9500, CEP 91501-970, Porto Alegre, RS, Brazil \\ ${ }^{2}$ Departamento de Zoologia, UFRGS, Av. Bento Gonçalves, 9500, CEP 91501-970, Porto Alegre, RS, Brazil \\ ${ }^{3}$ Departamento de Fitossanidade, UFRGS, Av. Bento Gonçalves, 7712, CEP 91540-000, Porto Alegre, RS, Brazil \\ Correspondence to: Célson Roberto Canto Silva, PPG Biologia Animal, UFRGS, Av. Bento Gonçalves, 9500, \\ CEP 91501-970, Porto Alegre, RS, Brazil, e-mail: cantosilva@ig.com.br
}

Received September 30, 2003 - Accepted December 19, 2003 - Distributed February 28, 2006

(With 5 figures)

\begin{abstract}
A mass marking-recapture experiment was carried out to study the dispersal of Gryon gallardoi (Brethes) (Hymenoptera: Scelionidae) in tobacco crops. Parasitoids emerged in the laboratory were marked with dye powder. Six separate field trials were conducted in Jan/Feb 2002 involving the simultaneous release of marked parasitoids. Dispersal was determined by the recapture of individuals in sets of sticky and Moericke traps arranged in three concentric circles arranged at $1.4 \mathrm{~m}$ intervals from the central point of release. Traps were checked 4, 8, 24, 28, 32 and $48 \mathrm{~h}$ after parasitoid release and weather data were recorded at 2-h intervals from 9 to $17 \mathrm{~h}$ at the site. Of the 699 marked parasitoids released, 91 were recaptured (13.02\%). Fewer females were recaptured in the late afternoon, suggesting they are less active than males after dusk. G. gallardoi recaptures were not associated with average wind direction in any trials. After eight hours of release, recaptures occurred mostly in the traps farthest from the release point, suggesting that the experimental area was small in relation to the dispersal capacity of the parasitoid. Fitting a 4-h-after-release density-distance curve to a geometric model and considering a daily activity of $12 \mathrm{~h}$, the female dispersal capacity was estimated to be at least $7.6 \mathrm{~m} /$ day. The values reported here must be considered as indicative of the potential for active dispersal under the particular experimental conditions of these trials. It is possible that G. gallardoi may disperse downwind much farther than the distance recorded in this study.
\end{abstract}

Keywords: insecta, parasitism, Gryon gallardoi, movement, marking-recapture.

\section{RESUMO}

\section{Dispersão do parasitóide de ovos Gryon Gallardoi (Brethes) (Hymenoptera: Scelionidae) em cultivo de fumo}

Um experimento de marcação e recaptura foi desenvolvido para estudar a dispersão de Gryon gallardoi (Brethes) (Hymenoptera: Scelionidae) em cultivo de fumo. Parasitóides emergidos em laboratório foram marcados com pó de corante. Em seis ocasiões distintas, de janeiro a fevereiro de 2002, foram feitos experimentos de campo nos quais parasitóides marcados foram liberados ao mesmo tempo. A dispersão foi determinada pela recaptura de indivíduos em grupos de armadilhas (adesivas e de bandeja com água) dispostas em três círculos concêntricos com intervalos de $1,4 \mathrm{~m}$ a partir do ponto central de liberação. As armadilhas foram monitoradas 4, 8, 24, 28, 32 e 48 h após a liberação dos parasitóides e dados climáticos foram obtidos a cada duas horas, das $9 \mathrm{~h}$ às $17 \mathrm{~h}$, na área experimental. De 699 parasitóides marcados liberados, 91 foram recapturados (13,02\%). Fêmeas foram menos recapturadas ao final da tarde, sugerindo que elas são menos ativas que os machos no período crepuscular. A recaptura de G. gallardoi não foi associada à direção média do vento em todas as ocasiões de liberação. Após oito horas das liberações, a maioria das recapturas ocorreram em armadilhas localizadas mais distantes do ponto de liberação, sugerindo 
que a área experimental foi pequena em relação à capacidade de dispersão do parasitóide. A partir do ajuste da curva de densidade média de recapturas nas diferentes distâncias aferida 4 h após as liberações ao modelo geométrico e considerando uma atividade diária de $12 \mathrm{~h}$, foi estimada uma capacidade de dispersão para fêmeas de no mínimo 7,62 m/dia. Os valores aqui apresentados devem ser considerados como um indicativo do potencial para a dispersão ativa nas condições particulares do experimento. É possível que G. gallardoi, com a ajuda do vento, possa dispersar distâncias muito maiores do que a registrada neste estudo.

Palavras-chave: insecta, parasitismo, Gryon gallardoi, movimento, marcação-recaptura.

\section{INTRODUCTION}

The interplay between environmental heterogeneity and individual movement is an extremely important aspect of ecological dynamics (Turchin, 1998). Therefore, the quantification of the movement patterns of organisms is necessary information to underpin theories on spatial dynamics and population management.

Dispersal is a major trait of the life-history of insects, often believed to be a stabilizing force in their population dynamics (Stein et al., 1994). Dispersal patterns of herbivore insects in agroecossystems have been associated to pest outbreaks (Kareiva, 1982). On the other hand, studies on the dispersal of natural enemies have demonstrated the importance of movement in the efficiency of inundative releases (Saavedra et al., 1997; McDougall \& Mills, 1997) and in the establishment of insects introduced for insect pest control (Hopper \& Roush, 1993). Physical factors such as wind, temperature and humidity may influence the dispersal patterns of biocontrol agents, particularly for small organisms such as parasitoids, and thus play an important role in biological control by inundative release. Despite the critical role of movement, there is a marked lack of information on the flight behavior and mobility of biocontrol agents (Corbett \& Rosenheim, 1996).

Studies on insect dispersal generally consist of mass marking-recapture (MMR), i.e., marking a large number of organisms, releasing them at a particular point in space and recapturing individuals later, after they have had an opportunity to move around (Turchin, 1998). A crucial step in this technique is the method for marking insects. Several methods used for general insects are unreliable for small delicate parasitoids (Hagler et al., 2002). In such cases, methods in which manipulation is minimal, such as self-marking with fluorescent or another type of dye powder, are advisable (Corbett \& Rosenheim, 1996). The end product of a MMR study is "density-distance data" and quantitative analyses are carried out by testing the adjustment to some functional relationships derived from phenomenological or mechanistic models (Turchin, 1998).

The gray-tobacco-bug, Spartocera dentiventris (Berg) (Hemiptera: Coreidae), is a species associated with the tobacco crop and may cause economic losses by curling and withering of the attacked leaves (Schaefer \& Panizzi, 2000). Previous experiments to ascertain the role of the egg parasitoid Gryon gallardoi (Brethes) (Hym.; Scelionidae) in the control of $S$. dentiventris have demonstrated that this species is responsible for about $50 \%$ of the egg mortality observed for the bug (Santos et al., 2001). Several laboratory and field studies have involved investigations into the $G$. gallardoi - S. dentiventris interaction (Wiedemann et al., 2003; Canto-Silva, 2003). Jesus et al. (2002a,b) studied the spatial dispersion and movement pattern of the coreid on tobacco plants. The dispersal of G. gallardoi, however, had not yet been investigated. Thus, this study was conducted to obtain information on how G. gallardoi disperses through tobacco crops, focusing on the diel movement pattern, the general influence of weather factors on displacement, and the distance covered in short range dispersal.

\section{MATERIALS AND METHODS}

The work was carried out at the "Departamento de Fitossanidade, Faculdade de Agronomia, Universidade Federal do Rio Grande do Sul" in Porto Alegre ( $30^{\circ} 01^{\prime} \mathrm{S}$ and $\left.51^{\circ} 13^{\prime} \mathrm{W}\right)$, RS, Brazil, in January/February 2002.

G. gallardoi were reared from field-collected parasitized $S$. dentiventris eggs. The parasitoids were kept in transparent plastic bottles $(500 \mathrm{~mL})$ 
in the laboratory $\left(25 \pm 1{ }^{\circ} \mathrm{C}, 12\right.$-h photophase $)$ and fed (10\% aqueous honey solution) ad libitum. Non-parasitized younger than 24 h-old $S$. dentiventris egg groups were provided daily to maintain the parasitoid population. These eggs were obtained from an experimental tobacco crop, where $S$. dentiventris females were kept on the plants, in voile fabric cages which impeded field parasitization.

A tobacco plot close to the laboratory was used for the G. gallardoi dispersal study. Eighty-one plants, $0.8 \mathrm{~m}$ apart along rows and $1.0 \mathrm{~m}$ between rows (Fig. 1), were cultivated following the normal practices for commercial crops, except that insecticides and anti-budding chemicals were not applied.

The day before the trial, Petri dishes with a known number of eggs parasitized by G. gallardoi in an advanced stage of development were impregnated with non-water soluble powder dye. Different colors of dye powder were used in each release trial. Self-marking occurred when individuals emerged from their hosts and walked about the dish. The following day, the dishes with newly-emerged marked parasitoids were placed in the field suspended by a trellis $1.50 \mathrm{~m}$ above the ground and then opened. After half an hour, the dishes were removed and the number of nonemerged and dead parasitoids remaining in the dishes was counted to determine the number of parasitoids released. The sex ratio for the species was previously determined under similar rearing conditions (0.79) (Canto-Silva, 2003). The number of males and females released were estimated based on this ratio and emerged adults did not require manipulation, thus keeping disturbance to a minimum.

Six separate release trials were conducted in January/February 2002, when marked parasitoids were released in the middle of the experimental area. To recapture marked G. gallardoi, twenty sets of traps were arranged in three successive concentric circles placed $1.4 \mathrm{~m}$ apart starting from the central release point and then from each other

$\mathrm{N}$

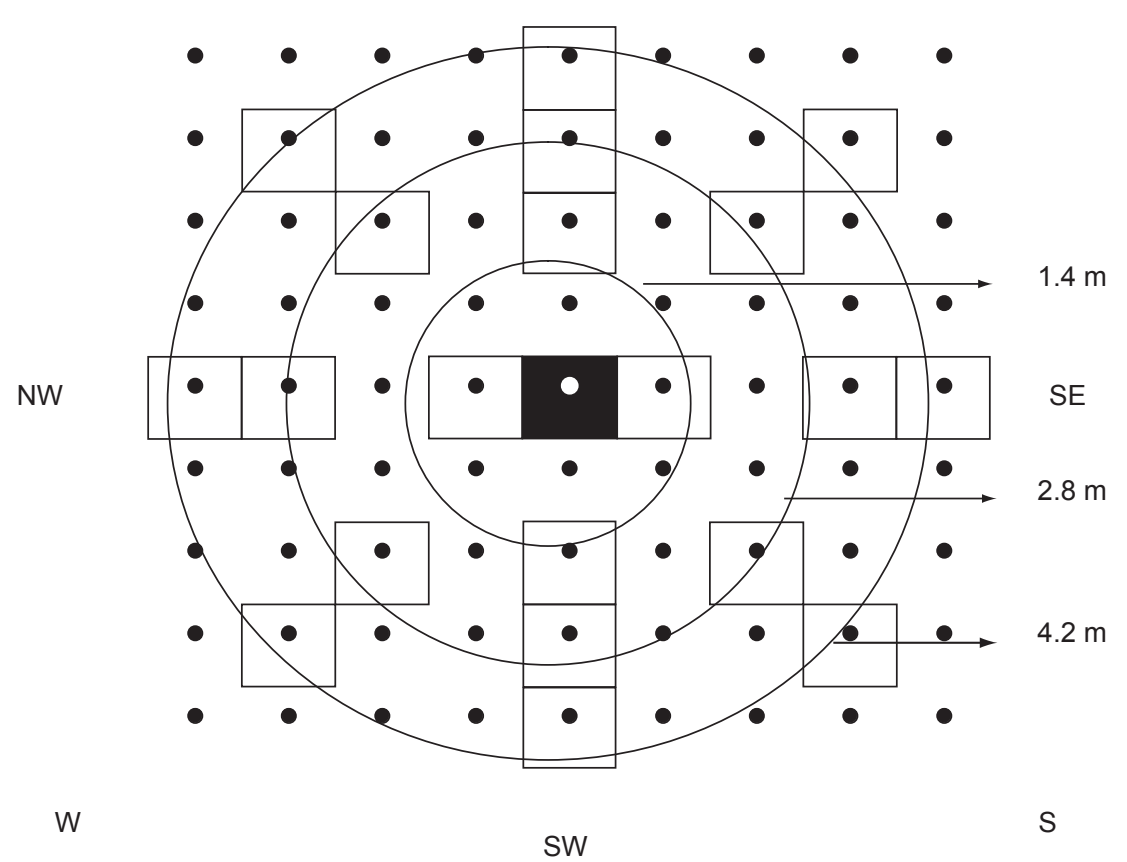

Fig. 1 - Sketch of the experimental plot arrangement showing tobacco plants (points), trap sets (white blocks) and release point (black block) used for evaluation of Gryon gallardoi dispersal. Porto Alegre (30 05' S and 51 $13^{\circ}$ ' W), RS, Brazil, Jan/Feb 2002. Letters indicate cardinal points. 
(Fig. 1). Each set of traps consisted of double-sided yellow sticky traps $(10 \times 15 \mathrm{~cm})$ and a Moericke trap $(\varnothing=22 \mathrm{~cm})$ fastened to a trellis about $1 \mathrm{~m}$ above the ground. Three females and two males of $S$. dentiventris were kept inside voile cages in the plants close to each set of traps. Except for these, the plot remained free of $S$. dentiventris individuals during release trials. Parasitoids were released at $9 \mathrm{~h}$ in all the trials and then six checks were carried out during the next two days: $4,8,24,28,32$ and $48 \mathrm{~h}$ after release. Captured parasitoids were examined under a stereomicroscope to determine whether they were marked.

On the sampling days, the air temperature, humidity and wind direction and speed were monitored at the release point with a portable thermo-hygro-anemometer at 2-h intervals from 9 to $17 \mathrm{~h}$. To assess the influence of wind on the displacement of recaptured parasitoids, the average wind direction was calculated for the period during which dispersal was monitored in each markingrecapture trial $\left(\mathrm{NE}=0^{\circ}, \mathrm{SE}=90^{\circ}\right.$, etc.). A line was drawn through the central point and perpendicular to the average wind direction, yielding two sectors. Recaptures were classified then as upwind or downwind of the release point based on their direction relative to this line. A $\chi^{2}$ analysis was carried out to determine whether recaptures could be associated to wind direction.

The recapture rate was calculated based on the number of parasitoids marked versus the number recovered on the traps. The small scale of the area did not generate data that could be subject to stronger quantitative analysis, such as adjustment to diffusion models (Turchin, 1998). Dispersal analysis was performed by the adjustment of density-distance data to phenomenological models described in the literature (Taylor, 1978). The daily dispersal distance was estimated based on the median dispersal distance calculated from the fitted density-distance curve (Turchin, 1998).

Differences in the frequency of recapture and diel pattern between males and females were compared through goodness of fit to a $\chi^{2}$ distribution (Sokal \& Rohlf, 1981).

\section{RESULTS AND DISCUSSION}

A total to 699 parasitoids were released on the six trials and, subsequently, 157 individuals of G. gallardoi were captured on the traps, 91 of which were marked. The recapture rate was $13.02 \%$ (Table 1). Given the number of parasitoids released and the number of traps, this recapture rate can be considered relatively high, since previous studies reported lower rates. Using baited yellow plastic traps and a large number of released Psyttalia fletcheri (Silvestri) (Hymenoptera: Braconidae) in three crops, Messing et al. (1995) achieved a recapture rate of $0.6 \%$. In a study of Anastrepha spp. (Diptera: Tephritidae) in an orchard, Bressan $\&$ Teles (1991) observed a rate of $6.7 \%$. On the other hand, Corbett \& Rosenheim (1996) obtained an average recapture rate of about $21 \%$ for three release trials of the minute parasitoid Anagrus epos Girault (Hymenoptera: Mymaridae) using sticky card traps.

Most of the parasitoids captured (57.9\%) were marked, confirming the efficiency of the marking method. Also, only a few dye particles marked the bodies of parasitoids, suggesting minimal potential effects on their behavior or survival. Bressan \& Teles (1991) found the same results for Anastrepha spp. (Diptera: Tephritidae) marked with metallic complex dye (aniline). In the present work, although the marking method was successful, particles of dye were sometimes hard to detect under the stereomicroscope. Therefore, dye particles should be used with moderation, particularly when compared with fluorescent powder, which is easily detectable under high-intensity illumination (Corbett \& Rosenheim, 1996).

On the whole, more males (51) than females (40) were recaptured. This ratio was significantly different from what had been expected based on the estimated sex ratio for the species $(0.79$; Canto-Silva, 2003) $\left(\chi^{2}=63.20 ;\right.$ d.f $\left.=1 ; p<0.0001\right)$. An analysis of the data from the standpoint of the time of day recaptures took place revealed that the sex ratio was close to that expected for most of periods $\left(13 \mathrm{~h}, \chi^{2}=2.39\right.$, d.f $=1, \mathrm{p}=0.122 ; 17 \mathrm{~h}$, $\chi^{2}=2.39$, d.f $=1, \mathrm{p}=0.122 ; 13 \mathrm{~h}, \chi^{2}=0.07$, d.f $=1$, $\mathrm{p}=0.794 ; 17 \mathrm{~h}, \chi^{2}=1.86$, d.f $\left.=1, \mathrm{p}=0.173\right)$ (Fig. 2). In fact, recaptures of males were more numerous only at $9 \mathrm{~h}$ on two successive days $\left(\chi^{2}=77.47\right.$, d.f $=1, \quad \mathrm{p}<0.0001$ and $\chi^{2}=18.34, \quad$ d.f $=1$, $\mathrm{p}<0.0001$ ) (Fig. 2). The fact that individuals monitored at $9 \mathrm{~h}$ corresponded to recaptures occurring after $17 \mathrm{~h}$ of the previous day suggests 
TABLE 1

Number and frequency of recaptured marked individuals of G. gallardoi in six marking-recapture trials. Porto Alegre (30 ${ }^{\circ}$ 05' S and 51 ${ }^{\circ}$ 13' O), RS, Brazil, Jan/Feb 2002.

\begin{tabular}{|c|c|c|c|c|}
\hline Trial & Release day & $\mathbf{N}$ & $\begin{array}{c}\text { Recaptured } \\
\text { (n) }\end{array}$ & $\begin{array}{c}\text { Recapture rate } \\
(\%)\end{array}$ \\
\hline 1 & $\operatorname{Jan} 23$ & 138 & 5 & 3.62 \\
\hline 2 & Jan 29 & 133 & 26 & 19.55 \\
\hline 3 & Feb 05 & 128 & 17 & 13.28 \\
\hline 4 & Feb 08 & 73 & 20 & 27.40 \\
\hline 5 & Feb 10 & 100 & 18 & 18.00 \\
\hline \multirow[t]{2}{*}{6} & Feb 12 & 127 & 5 & 3.94 \\
\hline & Total & 699 & 91 & 13.02 \\
\hline
\end{tabular}

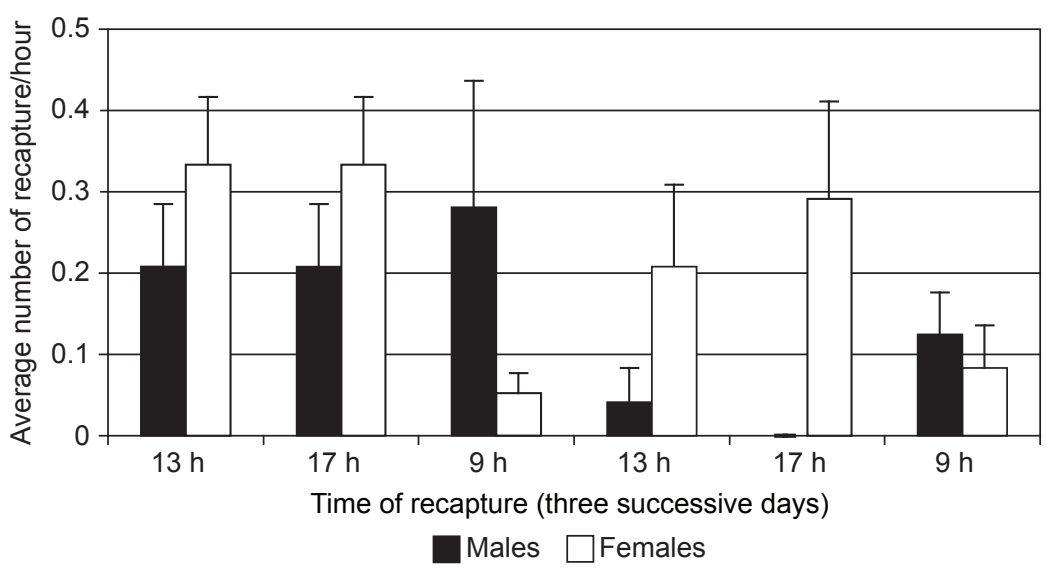

Fig. 2 - Average number of recaptured males and females of Gryon gallardoi per hour at each time of monitoring along three successive days after release in a tobacco plot. Porto Alegre (30 05' S and 51 ${ }^{\circ} 13^{\prime} \mathrm{W}$ ), RS, Brazil, Jan/Feb 2002.

an after dusk pattern of activity for males. Laboratory observations have shown males and females of G. gallardoi are active in the morning. In contrast, in the evening these wasps present a resting behavior. A cyclical resting behavior pattern was also observed by Vogt \& Nechols (1991) for Gryon pennsylvanicum (Ashmead) (Hymenoptera: Scelionidae) under laboratory and field conditions. Asante et al. (2000) observed the same pattern for Gryon fulviventris (Crawford) (Hymenoptera: Scelionidae), an egg parasitoid of Clavigralla tomentosicollis Stal (Hemiptera; Coreidae), with adults active only during the day (i.e., from 6 to $17 \mathrm{~h}$ ). Thus, it is probable that the males recorded at $9 \mathrm{~h}$ in this study corresponded to recaptures occurring during the late afternoon/dusk hours, suggesting that females are less active than males at this time of day. It is also interesting to note that females tolerate high daily temperature and low humidity, since their active behavior coincided with peak daily field temperatures (about $30{ }^{\circ} \mathrm{C}$ ) during the experimental trials (Fig. 3). This is a very important finding for a potential biocontrol agent.

The average wind direction over the two days of trials was $258.8^{\circ}, 215^{\circ}, 225^{\circ}, 61.88^{\circ}, 77.4^{\circ}$ and $198^{\circ}$ for the six trials, respectively (Fig. 4). Taking these values as a reference, most recaptures in each trial were downwind $(60 \%, 61.5 \%, 58.8 \%$, $55 \%, 50 \%$ and $80 \%$ for the six trials, respectively) (Fig. 4). However, a $\chi^{2}$ analysis did not indicate these Figs. were significantly different from random dispersal with respect to wind direction in any of the trials $\left(\chi^{2}=0.2 ;\right.$ d.f $=1 ; \mathrm{p}=0.655 ; \chi^{2}=1.4$; 


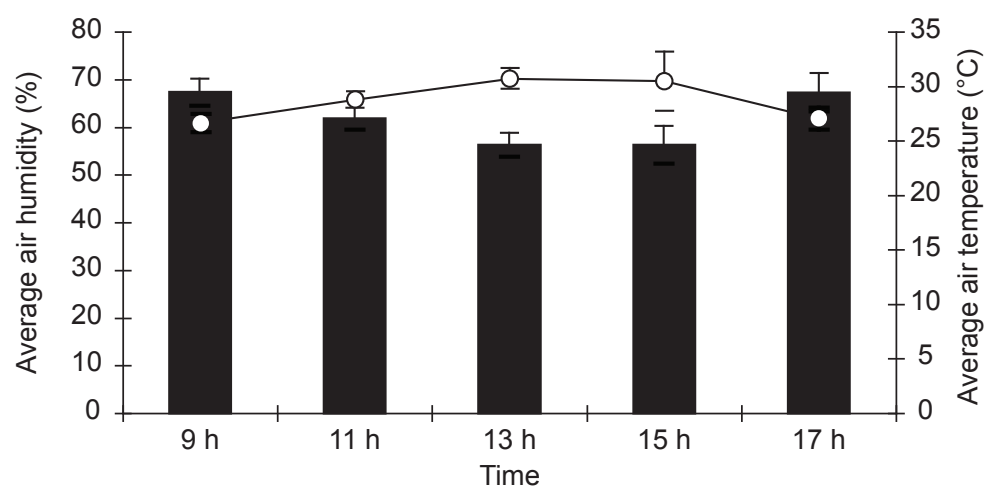

Fig. 3 - Average air temperature (line) and humidity (columns) throughout the day during the experimental trials of Gryon gallardoi dispersal in a tobacco plot. Porto Alegre (30 $05^{\prime} \mathrm{S}$ and $\left.51^{\circ} 13^{\prime} \mathrm{W}\right), \mathrm{RS}$, Brazil, Jan/Feb 2002.

Trial 1

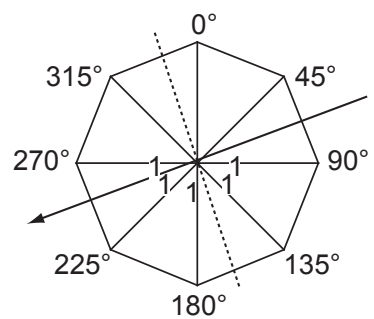

$258.8^{\circ}$

Trial 3

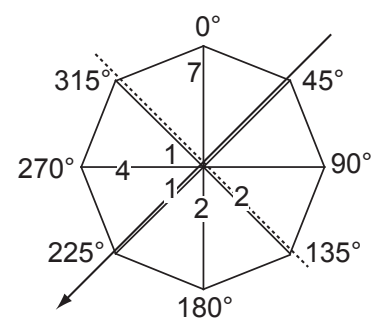

$225^{\circ}$

Trial 5

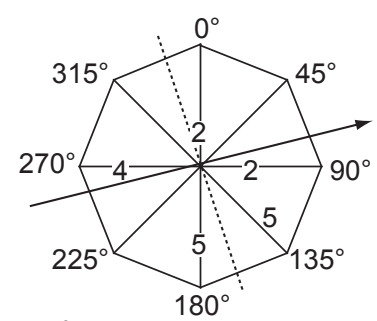

$77.4^{\circ}$
Trial 2

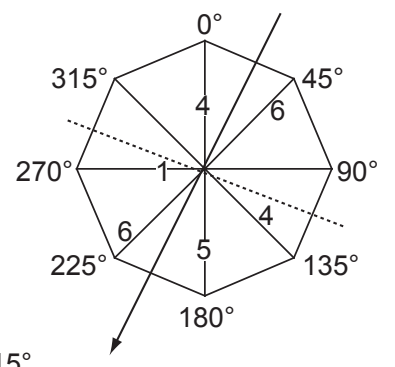

Trial 4

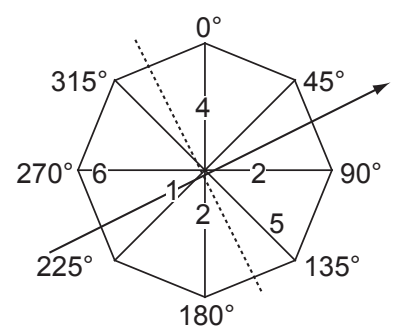

$61.88^{\circ}$

$198^{\circ}$

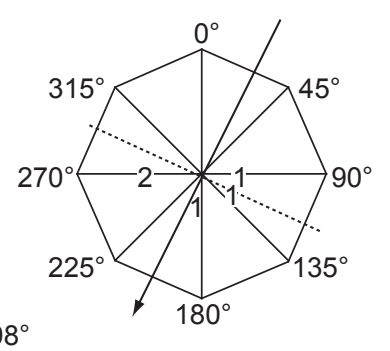

Fig. 4 - Distribution of Gryon gallardoi recaptures (numbers) in relation to line (discontinue line) drawn perpendicular to the average wind direction (arrow) in six marking-recapture trials, determining downwind and upwind dispersal. The number in the left corner indicates average wind direction. Porto Alegre (30 05' S and 51 ${ }^{\circ} 13^{\prime}$ W), RS, Brazil, Jan/Feb 2002. 
d.f $=1 ; p=0.239 ; \chi^{2}=0.5 ;$ d.f $=1 ; p=0.467 ;$ $\chi^{2}=0.2 ;$ d.f $=1 ; \mathrm{p}=0.655 ; \chi^{2}=0 ;$ d.f $=1 ; \mathrm{p}=1 ;$ $\chi^{2}=1.8 ;$ d.f $=1 ; \mathrm{p}=0.179$, respectively for the six trials). Average wind speeds for the trials were, respectively, $0.5,0.9,0.4,1.4,1.0$ e $0.4 \mathrm{~m} / \mathrm{s}$, with a maximum speed of $3.9 \mathrm{~m} / \mathrm{s}$ at $15 \mathrm{~h}$ of the fourth trial.

Since most egg parasitoids are small insects, one would expect their flight speed to be low and therefore their ability to fly against prevailing winds to be rather limited (Chapman, 1982). Thus, a pattern of downwind dispersal would be expected. However, this is not always clearly observed for parasitoid dispersal. Messing et al., (1995) reported a clear downwind dispersal only for males of $P$. fletcheri in mixed crops. Females presented as much downwind as upwind dispersal, this pattern being associated to positive anemotaxis to odors carried on the wind. Studying the dispersal of Trichogramma pretiosum (Riley) (Hymenoptera: Trichogrammatidae) in cotton, Saavedra et al. (1997) reported that the average wind speed on the release days was low, allowing for uniform parasitoid dispersal in the experimental area. Likewise, there were no indications that wind speed influenced the dispersal of Trissolcus basalis (Wollaston) (Hymenoptera: Scelionidae) in tomato crops (Justo et al., 1997). Corbett \& Rosenheim (1996) observed an upwind pattern for A. epos dispersal in vineyards, and suggested this could arise from moderate wind speeds or by dispersal below the crop canopy where wind speeds are lower and upwind flight, oriented toward chemical cues, is easier. Since recaptures of G. gallardoi were random with respect to wind direction, is possible that the low average wind speed observed had little influence on parasitoid dispersal. Furthermore, it is also possible that parasitoids dispersed beneath the top of the tobacco canopy. The rejection of upwind dispersal may point to little influence of the wind on movement based on chemicals cues.

The number of recaptured individuals per trap placed at $1.4 \mathrm{~m}$ intervals from the central release point at different times along two days was averaged by hour and is shown in Fig. 5. Except for four and eight hours after releases, the average number of recaptures in all monitored times increased when distance in relation to the central point increased (Fig. 5). At eight hours, most of the individuals were recaptured at $1.4 \mathrm{~m}$, although the average number of recaptures at $4.2 \mathrm{~m}$ was higher than at $2.8 \mathrm{~m}$ from the release point. Only four hours after release, the recaptures showed a declining gradient as the distance from the central point increased (Fig. 5). This decline in density from a center of dispersal is frequently reported in the entomological literature (Taylor, 1978; Greatti \& Zandigiacomo, 1995; Messing et al., 1995; McDougall \& Mills, 1997) and is the basic premise of phenomenological models (Turchin, 1998). The density declines because few organisms will travel very far (as a result of a tendency to settle or due to limited life span) and due to dilution of individual numbers in a larger area at increased distances from the center (Turchin, 1998). Another factor responsible for this decline has been found in dispersal investigations using sentinel eggs, in which newly emerged parasitoids tend to oviposit in or near the colony in which they developed (Weisser \& Völki, 1997). Sometimes, as reported here, this density decline decreases over time (McDougall \& Mills, 1997). Therefore, the distance recapture pattern depends on: i) the parasitoid behavior; ii) the time after release; and iii) the size of the experimental area. Since the recapture pattern after eight hours seems to present saturation at longer distances from the release point (Fig. 5), it is suggested that the experimental area here was small relative to the dispersal capacity of the parasitoid. Thus, the appropriate time for measuring the dispersal of G. gallardoi in the present study was four hours after release, and only this subset was used to estimate the dispersal distance (Fig. 5).

Fitting exponential, logarithmic and geometric empirical models (Taylor, 1978) to the densitydistance curve four hours after release indicated that the geometric model presented the best agreement, albeit not significantly $\left(r^{2}=0.98 ; p=0.09\right.$; Fig. 5$)$. According to Taylor (1978), this model was used to describe viruses and insect dispersal. Based on the fitted model, an average distance displacement of $2.54 \mathrm{~m} / 4 \mathrm{~h}$ was calculated. The results reported here indicate little activity of females after dusk. Therefore, to estimate female G. gallardoi daily distance displacement, a 12-h period of daily activity was assumed, yielding a dispersal capacity of at least $7.62 \mathrm{~m} /$ day. This value is similar to those reported by Messing et al. (1995) and McDougall \& Mills (1997), who observed predominantly recapture and parasitism (on sentinel eggs) at 
4 hours
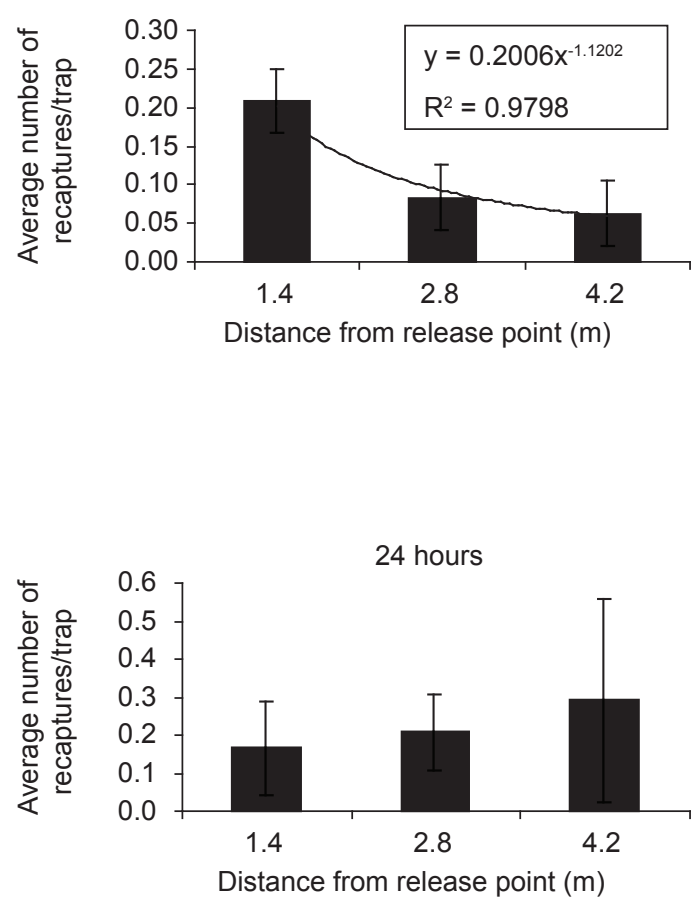

32 hours

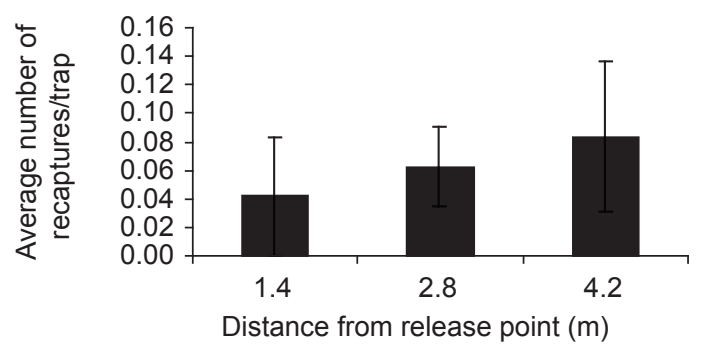

8 hours

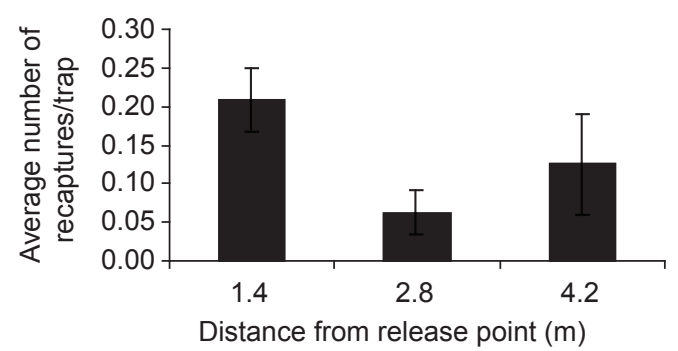

28 hours

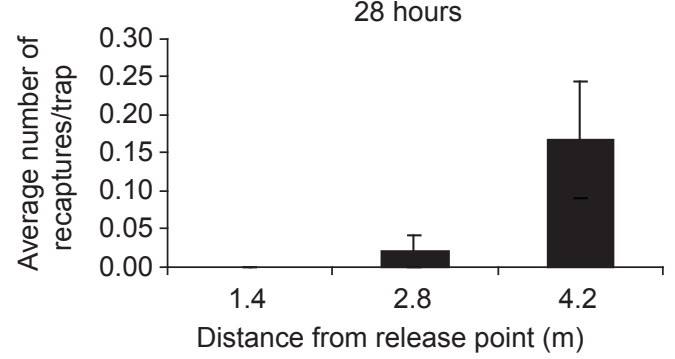

48 hours

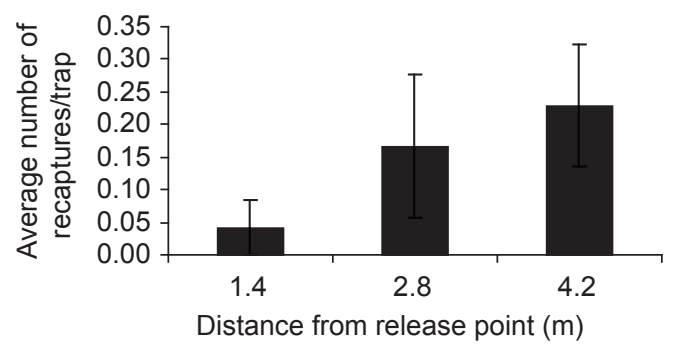

Fig. 5 - Average number of Gryon gallardoi recaptures per trap placed at $1.4 \mathrm{~m}$ intervals from the central release point in a tobacco plot on six occasions after release. Porto Alegre (30 $05^{\prime} \mathrm{S}$ and 51 ${ }^{\circ} 13^{\prime}$ W), RS, Brazil, Jan/Feb 2002.

distances of less than $15 \mathrm{~m}$ from the release point for P. Aletcheri and Trichogramma platneri Nagarkatti (Hymenoptera: Trichogrammatidae), respectively. For G. pennsylvanicum, Yasuda \& Tsurumachi (1995) reported recaptures in baited traps $50 \mathrm{~m}$ away from the release point three days after release, in a downwind direction.

The values reported here should be considered preliminary approximations of $G$. gallardoi dispersal since they are based on limited data. It is also considered that the estimated displacement values refer to active movement since, as mentioned above, little influence of wind on the parasitoid dispersal was detected. It is possible that downwind dispersal of G. gallardoi could be more marked than has been reported.

Acknowledgments - The authors thank the Departamento de Fitossanidade, Faculdade de Agronomia - Universidade Federal do Rio Grande do Sul for the use of its facilities for this study. This work was supported by CNPq (Brazil), process $n^{\circ} 471097 / 2001-2$. 


\section{REFERENCES}

ASANTE, S. K., JACKAI, E. N. \& TAMO, M., 2000, Efficiency of Gryon fulviventris (Hymenoptera: Scelionidae) as an egg parasitoid of Clavigralla tomentosicollis (Hemiptera: Coreidae) in northern Nigeria. Environ. Entomol., 29(4): 815-821.

BRESSAN, S. \& TELES, M. C., 1991, Recaptura de adultos marcados de Anastrepha spp. (Diptera: Tephritidae) liberados em apenas um ponto do pomar. Revta. Bras. Ent., 35(4): 679-684

CANTO-SILVA, C. R., 2003, Parâmetros bioecológicos de Gryon gallardoi (Brethes) (Hymenoptera: Scelionidae) e modelagem da dinâmica espaço-temporal da sua interação com Spartocera dentiventris (Berg) (Hemiptera: Coreidae) através da simulação de múltiplos agentes. Tese de doutorado, Universidade Federal do Rio Grande do Sul, Programa de Pós-Graduação em Biologia Animal, Instituto de Biociências, Porto Alegre, 210p.

CHAPMAN, R. F., 1982, The insects: structure and function. Harvard University Press, Cambridge, MA., 919p.

CORBETT, A. \& ROSENHEIM, J. A., 1996, Quantifying movement of a minute parasitoid, Anagrus epos (Hymenoptera: Mymaridae), using fluorescent dust marking and recapture. Biol. Control, 6: 35-44.

GREATTI, M. \& ZANDIGIACOMO, P., 1995, Postrelease dispersal of Trichogramma brassicae Bezdenko in corn fields. J. Appl. Ent., 119: 671-675.

HAGLER, J. R., JACKSON, C. G., HENNEBERRY, T. J. \& GOULD, J. R., 2002, Parasitoid mark-release-recapture techniques - II. Development and application of a protein marking technique for Eretmocerus spp., parasitoids of Bemisia argentifolii. Biocontrol Science and Technology, 12: 661-675.

HOPPER, K. R. \& ROUSH, R. T., 1993, Mate finding, dispersal, number released, and the sucess of biological control introductions. Ecol. Entomol., 18: 321-331.

JESUS, C. R., REDAELLI, L. R. \& ROMANOWSKI, H. P., 2002a, Population dynamics and spatial distribution of Spartocera dentiventris (Berg) (Hemiptera: Coreidae) adults on Nicotiana tabacum L. (Solanacea). Neotrop. Entomol., 31(4): 541-549.

JESUS, C. R., ROMANOWSKI, H. P. \& REDAELLI, L. R., 2002b, Movement pattern of Spartocera dentiventris (Berg) (Hemiptera: Coreidae) in an experimental crop of Nicotiana tabacum L. (Solanacea). Braz. J. Biol., 62(4B): 827-834.

JUSTO, H. D., SHEPARD, B. M. \& ELSEY, K., 1997, Dispersal of the egg parasitoid Trissolcus basalis (Hymenoptera: Scelionidae) in Tomato. J. Agric. Entomol., 14(2): 139-149.
KAREIVA, P., 1982, Experimental and mathematical analyses of herbivore movement: quantifying the influence of plant spacing and quality on foraging discrimination. Ecol. Monogr., 52(3): 261-282.

McDOUGALL, S. J. \& MILLS, N. J., 1997, Dispersal of Trichogramma platnery Nagarkatti (Hym., Trichogrammatidae) from point-source releases in an apple orchard in California. J. Appl. Ent., 121: 205-209.

MESSING, R. H., PURCELI, M. F. \& KLUNGNESS, L. M., 1995, Short range dispersal of mass-reared Psyttalia fletcheri (Hymenoptera: Braconidae), parasitoids of Bactrocera cucurbitae (Diptera: Tephritidae). Environ. Entomol., 24(5): 1338-1343.

SAAVEDRA, J. L. D., TORRES, J. B. \& RUIZ, M. G., 1997, Dispersal and parasitism of Heliothis virescens eggs by Trichogramma pretiosum (Riley) in cotton. J. Pest Manag., 43(2): 169-171.

SANTOS, R. S. S., REDAELLI, L. R. \& DIEFENBACH, L. M. G., 2001, Ocorrência de parasitismo em ovos de Spartocera dentiventris (Berg) (Hemiptera: Coreidae) em cultura de fumo. Neotrop. Entomol., 30(4): 731-733.

SCHAEFER, C. W. \& PANIZZI, A. R., 2000, Heteroptera of Economic Importance. CRC Press, Boca Raton, Florida, USA, 856p.

SOKAL, R. R. \& ROHLF, F. J., 1981, Biometry. $2^{\text {nd }}$ ed., New York, Freeman, 859p.

STEIN, S. J., PRICE, W. P., CRAIG, T. P. \& ITAMI, J. K, 1994, Dispersal of a galling sawfly: implications for studies of insect population dynamics. J. Anim. Ecol., 63: 666-676.

TAYLOR, R. A. J., 1978, The relationship between density and distance of dispersing insects. Ecol. Entomol., 3: 63-70.

TURCHIN, P., 1998, Quantitative analysis of movement: measuring and modeling population redistribution in animals and plants. $1^{\text {st }}$ ed., Sunderland, Sinauer associates, 396p.

VOGT, E. A. \& NECHOLS, J. R., 1991, Diel activity patterns of the squash bug egg parasitoid Gryon pennsylvanicum (Hymenoptera: Scelionidae). Ann. Entomol. Soc. Am., 84(3): 303-308.

WEISSER, W. W. \& VÖLKI, W., 1997, Dispersal in the aphid parasitoid, Lysiphlebus cardui (Marshall) (Hym., Aphidiidae). J. Appl. Ent., 121: 23-28.

WIEDEMANN, L.M.,CANTO-SILVA, C.R., ROMANOWSKI, H. P. \& REDAELLI, L. R., 2003, Oviposition behaviour of Gryon gallardoi (Hym.; Scelionidae) on eggs of Spartocera dentiventris (Hem.; Coreidae). Braz. J. Biol., 63(1): 133-139.

YASUDA, K. \& TSURUMACHI, M., 1995, Influence of male adults of the leaf-footed plant bug, Leptoglossus australis (Fabricius)(Heteroptera: Coreidae), on host-searching of the egg parasitoid Gryon pennsylvanicum (Ashmead) (Hymenoptera: Scelionidae). Appl. Entomol. Zool., 30(1): 139-144. 